\title{
工業化住宅内各部位の環境腐食性*
}

\author{
元田慎一**, 鈴木揚之助**, 篠 原 正 $^{* * *}$, 辻川茂男*** \\ ** 東京商船大学 \\ *** 東京大学大学院工学系研究科
}

\section{Corrosivity of Indoor Atmosphere for a Prefabricated House*}

\author{
Shin-ichi Motoda**, Yohnosuke Suzuki**, Tadashi Shinohara*** and Shigeo Tsujikawa*** \\ ** Tokyo University of Mercantile Marine \\ *** Graduate School of Engineering, The University of Tokyo
}

\begin{abstract}
An atomospheric exposure test has been conducted since Sept. 26, 1994 at a five member family steel framed prefabricated house in Nogi-chou, Shimotuga-gun, Tochigi prefecture. The ACM (Atmospheric Corrosion Monitor) corrosion sensors and zinc-coated steel coupons are exposed in nine indoor sites - ceilings, floors and wall cavities- and one outdoor site sheltered from rain. Three year of measured results are reported here. The ACM sensor outputs galvanic current, $I$, between carbon steel and silver, integral of which over a day -daily average electricity, $Q$ - is related to corrosion rates of carbon steel and zinc to be used as a measure of corrosivity for each site. The sensor output, $I$, is found to depend not only on relative humidity, $R H$, but also on amount of deposits on the sensor, which, expressed as equivalent amount of deposited sea salt, $W s$, is determined by referencing to $I$ vs. $R H$ relationship observed under various predetermined amounts of deposited sea salt in laboratory test. Corrosion rates of carbon steel and zinc at their indoor sites are around one fifth of the outdoor one. Such lower corrosion rates at the indoor sites are attributed mainly to lower $W s$ values which are around one tenth of the outdoor one. Moreover, amount of sulfur trioxide collected for a year is $0.001 \mathrm{mg} \mathrm{SO} / 100 \mathrm{~cm}^{2} /$ day at an indoors site, one twenty sixth of the outdoor one.
\end{abstract}

Key words: steel framed prefabricated house, indoor corrosion, corrosion monitor, ACM sensor, corrosion rate, carbon steel, zinc, amount of deposit, relative humidity.

\section{1.はじめに}

建設省が「工業化住宅性能認定制度」を 1973 年 (昭 和 48 年）に創設して以来, 1997 年現在で 24 年を経過 した。この事業を 1987 年（昭和 62 年） 5 月から引き 継いだ（財）日本建築センターでは, 審査項目のうち, 鋼材の防錆については部位・部品を数グループに大別 し，それぞれをめっき・塗膜厚などの適切な表面処理・

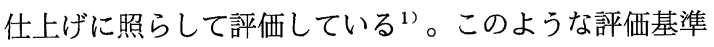
をより適正化し，対応する加速試験を開発するために

* 第 111 回腐食防食シンポジウム（大阪，1996 年） で一部発表

** 个135-8533 東京都江東区越中島 2-1-6 (2-1-6, Etchujima, Koto-ku, Tokyo, 135-8533 Japan)

*** 干113-8656 東京都文京区本郷 7-3-1 (7-3-1, Hongo, Bunkyo-ku, Tokyo, 113-8656 Japan)
も，まず各部位ごとの環境腐食性を定量化する必要があ る。

以下で述べるように，一般に屋外環境に比べ住宅内で の腐食速度は小さい。これは囲まれた空間内にあるため 外部から持ち込まれる付着物量が少ないからである。こ のように稳和な環境の腐食性デー夕を効率的に採取する ためには，高感度の腐食センサの適用が有効である。わ れわれはこれまでに, ACM (Atmospheric Corrosion Monitor) 型腐食センサを 4 か所の暴露地に設置 し, 主として海洋性大気環境の腐食性評価を試みてき た2),3)。本報では, ACM 型腐食センサを実際の工業化 住宅内の諸部位に暴露して, その出力を測定した 3 年間 の結果について報告する。 


\section{2. 亜鉛めっき鋼板試料・センサ類の暴露 方法}

積水ハウス(株) のご好意により, 栃木県 下都賀郡野木町にある鉄鋼系工業化住宅 （1985年 4 月竣工 : 家族 5 人が居住）におい て, 1994年 9 月 26 日（'94.9.26 とかく, 以 下同様）から ACM 型腐食センサならびに 新日本製鐵株式会社のご好意による溶融また は電気亜鉛めっき鋼板試料の暴露を開始し た。

暴露位置は Fig. 1 および Table 1 に示す 10か所の部位で, 試料およびセンサの表面が 通常は地面とほぼ垂直になるように設置し た。このうち, 浴室壁内 (Site 1), 浴室天 井裏 (Site 4), 床下 (旡房 : Site 5, 南面 和室 : Site 7), 小屋裏 (2 階押入天井裏 : Site 6 ) および屋外（測定器格納庫の直接雨 が当たらない軒下: Site 10）には, 温・湿 度センサ (神栄(株), 変換器 THT-130, セ ンサ THP-B4T) も併せて設置した。これ ら 6 部位では後述のように付着物量も決定で きる。

$\mathrm{ACM}$ センサ出力, $I$, の測定範囲は 0.1 $\mathrm{nA} \sim 100 \mathrm{nA}$ (分解能 $0.1 \mathrm{nA}$ ), $10 \mathrm{nA} \sim 10$ $\mu \mathrm{A}$ (分解能 $10 \mathrm{nA}$ ), および $1 \mu \mathrm{A} \sim 1 \mathrm{~mA}$ （分解能 $1 \mu \mathrm{A}$ ) である。なお, 暴露部位によっ てはセンサ出力のノイズレベルが大きいた め, '94.11. 30 から簡易型の RC ローパス フィルター(フィルター1) を，また’95.4. 27からは高性能のローパスフィル夕ー（フィ ルター2）を取り付けた。

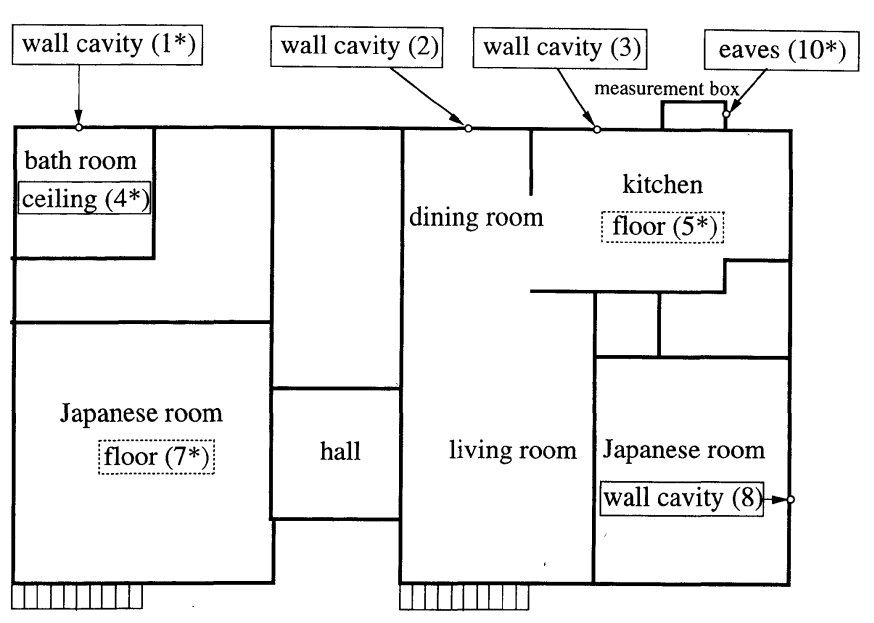

1st floor

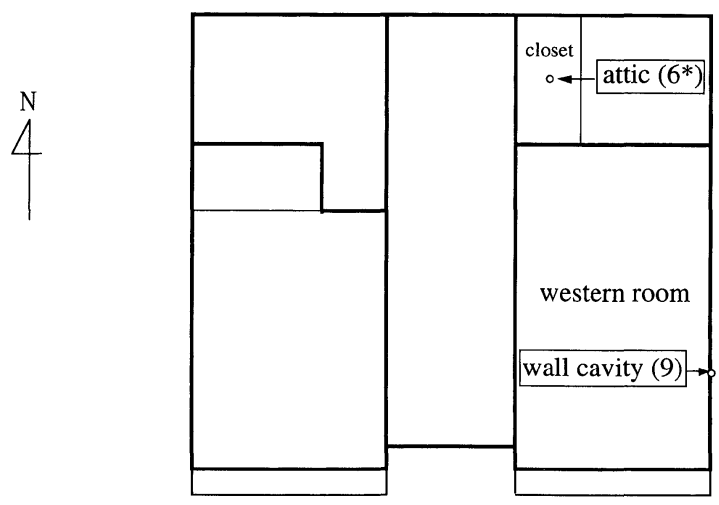

2nd floor

Fig.1 Plane view of exposure sites. Sites $1 \sim 10$ for ACM sensors, sites 1 9 for zinc-coated steel coupons and six sites marked by $\left({ }^{*}\right)$ for themo-hygrometers.

Table 1 Exposure sites of ACM sensor and thermo-hygrometer.

\begin{tabular}{|c|l|c|c|}
\hline Site & \multicolumn{1}{|c|}{ test area } & ACM sensor & Thermo-hygrometer \\
\hline 1 & wall cavity of bath room & $\bigcirc$ & $\bigcirc$ \\
\hline 2 & wall cavity of dining room & $\bigcirc$ & - \\
\hline 3 & wallcavity of kitchen & $\bigcirc$ & - \\
\hline 4 & ceiling for bath room & $\bigcirc$ & $\bigcirc$ \\
\hline 5 & kitchen floor & $\bigcirc$ & $\bigcirc$ \\
\hline 6 & attic (ceiling for closet) & $\bigcirc$ & $\bigcirc$ \\
\hline 7 & floor of Japanese room & $\bigcirc$ & $\bigcirc$ \\
\hline 8 & wall cavity of Japanese room (1st floor) & $\bigcirc$ & - \\
\hline 9 & wall cavity of western room (2nd floor) & $\bigcirc$ & - \\
\hline 10 & eaves of measurement box , outside the house & $\bigcirc$ & $\bigcirc$ \\
\hline
\end{tabular}




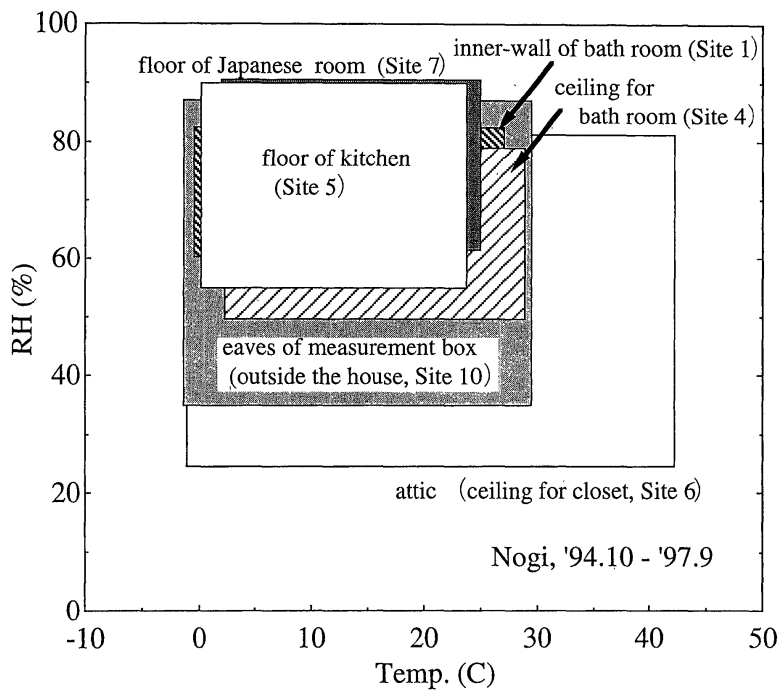

Fig.2 Range of $\mathrm{RH}$ and temperature at each site ('94.10-'97.9).

亜鉛めっき鋼板試料におけるめっき亜鉛（Zncかく） 部の腐食速度測定は精密化学法 ${ }^{4)}$ によった。これは $\mathrm{Zn}$ の腐食生成物が全量試料表面に残存する場合, その中の Zn（II）を定量することにより腐食速度を決定する方法 で，その部材の経過年数がわかれば初期重量の測定を必 要としない。

また, 大気中の $\mathrm{SO}_{3}$ 濃度の測定は, JIS Z 2381 に従 い $\mathrm{PbO}_{2}$ ペーストを塗布した円筒を' 96.10〜'97. 9 の 1 年間暴露しておこなった。

\section{3. 測定結果と考察}

\section{1 温度 . 湿度}

実際工業化住宅内各部位での温・湿度（相対湿度, $R H ）$ の 1 日内の最高・最低值を求め, それらの各月ご

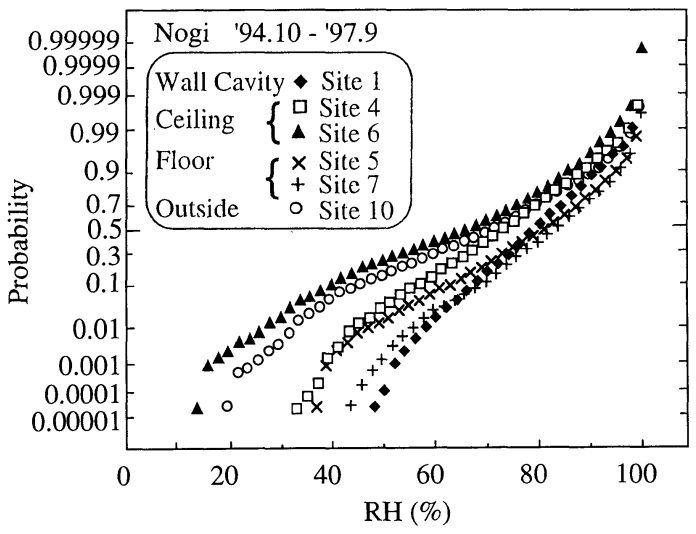

Fig.3 Normal probability plots of relative humidity at each exposure site for three years.
との平均值を算出した。3 年間（’94.10〜'97. 9) におけるこれら平均值の最高・最低值を, 各部位 ごとに取り得る温・湿度の範囲として Fig. 2 に 示す。小屋裏（Site 6 ）を除いて, 屋内の各部位 の温度・湿度の範囲は屋外（Site 10）のそれに ほぼ含まれている。ユニットバスの導入によるの か, 浴室の天井裏（Site 4) といっても高湿度に なっていない。ただし，床下（Site 5,7）では， 湿度の変動が小さく，かつ高めである。同じ期間 内において 10 分ごとに測定した湿度の累積確率 分布を Fig. 3 示す。平均值が約 $70 \%$ の Site $4 \cdot 6$ と 10 および約 $80 \%$ の Site 1 . 5 と 7 がある。

\section{2 センサ出力・海塩相当付着量}

屋外(Site10)では’94.12.1 から,またSite1, 2, 3, 5, 7 および 9 では’ 95.4 から有意なセンサ出力 が検出された。Site 4 (浴室天井裏)とSite 6 (小

屋裏）では当初から’ 97.9 現在まで出力は $10^{-4}$ $\mu \mathrm{A}$ 以下である。' 96.8.10〜8.12 における ACM センサ 出力ならびに $R H$ の経時変化例を Fig. 4 に示す。床下

(Site 5 ) の $R H$ は $80 \%$ 以上であり，1 日内の変動も 屋外（Site 10）ほどは大きくない。そのため Site 5 の センサ出力も $(3 \sim 10) \times 10^{-4} \mu \mathrm{A}$ と変動は小さく, $10^{-4}$ $\sim 10^{-1} \mu \mathrm{A}$ と変動の大きい Site 10 とは対照的である。

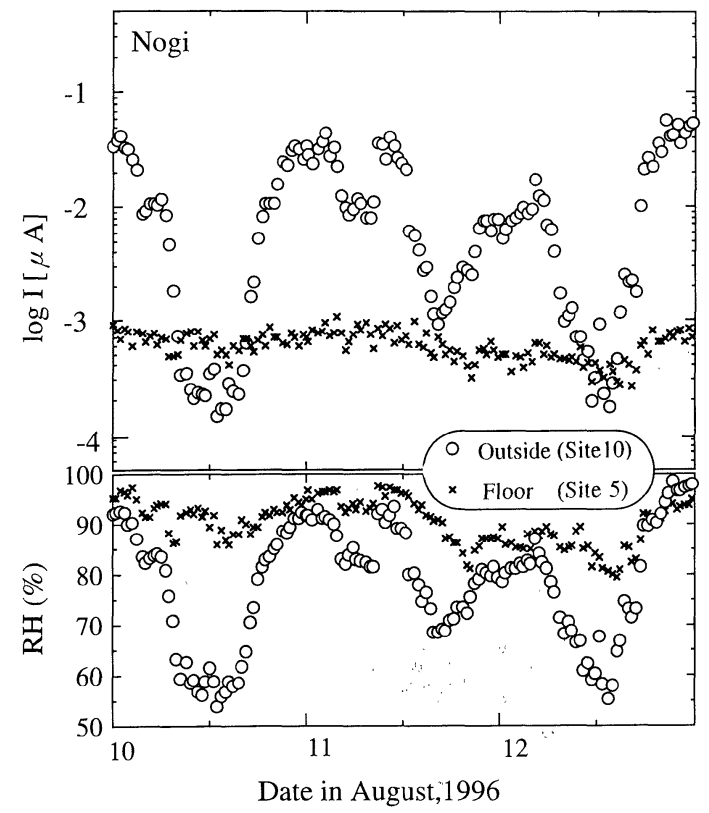

Fig.4 Example of time variations of ACM sensor output, $I$, and relative humidity, $R H$, at Site 5 (kitchen floor) and Site 10 (outside the house). 
' 96. 8.10〜8.11 における Site 1，4，5，6，7および 10 での $I$ vs. $R H$ の関係を Fig. 5 に示す。図中の実線 は $10^{-4} \sim 10^{0} \mathrm{~g} / \mathrm{m}^{2}$ の海塩を付着させたセンサにおける $I$ vs. $R H$ の関係（較正曲線とよぶ）である。これらと 実データとを照合して決定される Site 1, 5 および 7 に おける海塩相当付着量（以下,「海塩」付着量と記す） は $(3 \sim 4) \times 10^{-4} \mathrm{~g} / \mathrm{m}^{2}$ であり, Site 10 では約 $3 \times 10^{-3}$ $\mathrm{g} / \mathrm{m}^{2}$ である。また, Site $4(\square) \cdot 6(\Delta)$ については $10^{-4} \mu \mathrm{A}$ 超のセンサ出力が検出されず, この場合の付着

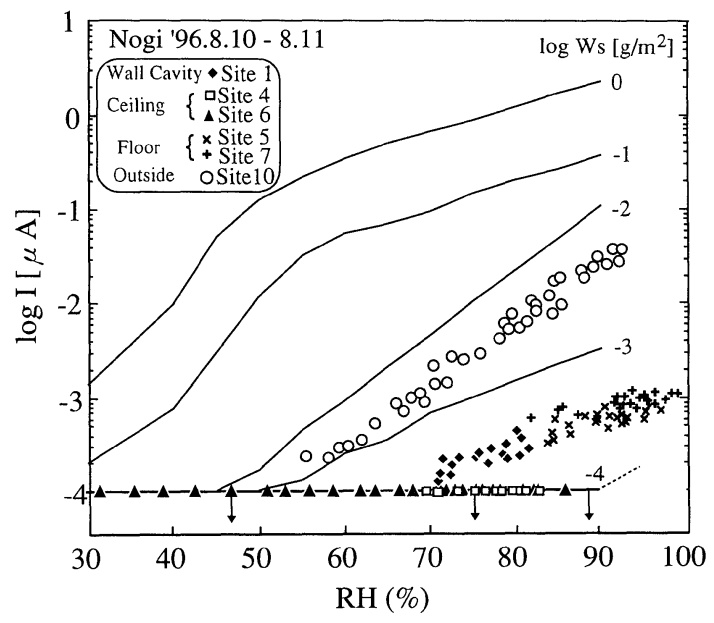

Fig.5 Relationship between ACM sensor output, $I$, and $R H$ at Sites $1,4,5,6,7$ and 10 with respect to the calibration curves obtained under various predetermined amount of sea salt, Ws, deposited on the ACM sensor.

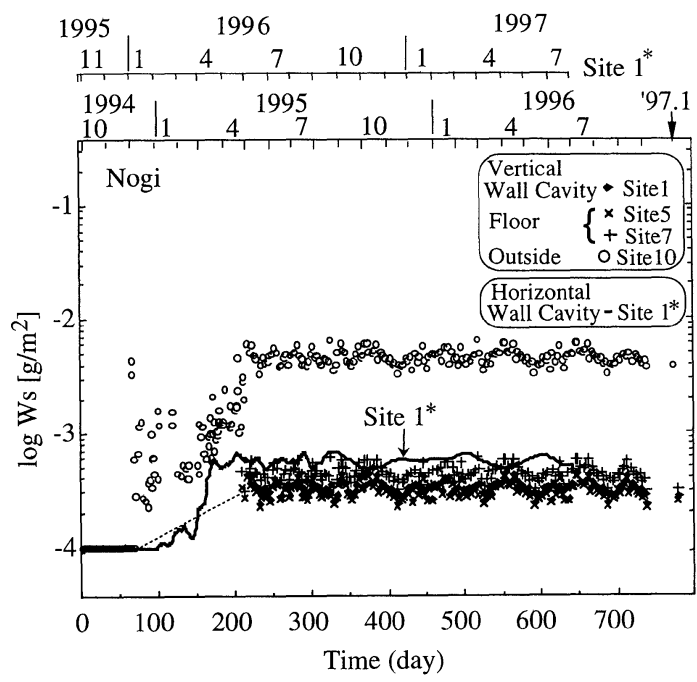

Fig.6 Variation with exposure time of equivalent amount of deposited sea salt, Ws, estimated at each site.
量は $1 \times 10^{-4} \mathrm{~g} / \mathrm{m}^{2}$ 末満である。 $10^{-4} \mu \mathrm{A}$ 超の有意な出 力が検出された Site 1, 5, 7, および 10 について, 3 年 間（'94.10〜'97.9）における「海塩」付着量の経時変化 を求め, 結果を Fig. 6 に示す。屋外（Site 10）の「海 塩」付着量は, 暴露開始後約 200 日で定常的になり，そ の值 $(4 \sim 6) \times 10^{-3} \mathrm{~g} / \mathrm{m}^{2}$ は静岡県清水市における暴露 台のそれ $10^{-2} \sim 10^{-1} \mathrm{~g} / \mathrm{m}^{2}$ (文献 (2)) の 1/20〜1/2 で ある。屋内の部位については, 暴露開始からフィルター 2 を取り付けた’ 95.4.27 まではセンサ出力が検出でき ていないが，屋外（Site 10）とほぼ同じ時期に定常に なったものと考えられる。上述のように Site 1, 5 およ び 7 における「海塩」付着量は部位間にほとんど差はな く(3〜4) $\times 10^{-4} \mathrm{~g} / \mathrm{m}^{2}$ で, 屋外の約 $1 / 10$ であるこの ような挙動は, センサを垂直に設置したためであろう か。この点の検討のため, '95.10.25 より Site 1 に水平 上向きに設置したセンサ（Site $1^{*}$ ) では，約 120 日後 （'96.2 下旬）から「海塩」付着量が増加し始め, 約 170 日でほぼ定常的付着量 $6 \times 10^{-4} \mathrm{~g} / \mathrm{m}^{2}$ となった。この付 着量は垂直に設置したセンサの約 2 倍である。垂直/水 平上向きーいずれの置き方でも, 数箇月以上の誘導期間 を経て定常的付着量が形成されるようである。

Fig. 6 と同じ 3 年間における $\mathrm{ACM}$ センサ出力の日 平均電気量 $(Q)$ と $R H$ の月別変動 $(\mu \pm \sigma, \mu$ : 平均, $\sigma$ : 標準偏差) を Fig. 7 に示す。Fig. 2 および Fig. 3 と同様, 屋内の Site 1, 4,7の $R H$ は屋外 (Site 10) に 比べて高く, かつ変動が小さい。「海塩」付着量が定常 になった’ 95.5 以降でみると, 屋外（Site 10）での $Q$ は 6〜9月の夏期で大きく 11〜3月の冬期で小さい。 '96,' 97 とも, 2 月で最も小さくなっている。これに対 し, 屋内（Site 1，7）の $Q$ では 2 月に小さいのは屋外 と同様であるが，8月においても極小值をとることがあ り,これらは $R H$ の変化とはむしろ逆である。屋内の $Q$ は屋外のおおよそ $1 / 100$ (5〜 月) 1/10（11～3 月） となっている。

\section{3 付着物量と湿度条件とが与えられた環境での日 平均電気量の推定}

$\mathrm{ACM}$ センサ出力 $I$ は, $W s$ と $R H$ との関数 $I=I(W s$, $R H ）$ として表せる。所定の測定期間 $T$ [s] における センサ出力の全電気量 $Q_{T}[\mathrm{C}]$ は

$$
Q_{T}=\sum_{i=1}^{N T} I(W s, R H)_{i} \cdot \Delta t
$$

ここで, $\Delta t$ は測定間隔, $N T$ は測定期間 $T$ 内での測定 回数 $(T / \Delta t)$ である。

住宅内環境では部位ごとに Fig. 6 で示したように $W s$ はほぼ定常になるから，各部位での出力 $I$ はそれぞ れの $W s$ 一定条件下での $I$ vs. $R H$ 曲線 $I_{\mathrm{ws}}(R H)$ に 沿って変化することになる。すなわち： 


$$
\begin{aligned}
Q_{T} & =\sum_{i=1}^{N T} I_{W s}\left(R H_{i}\right) \cdot \Delta t \\
& =\sum_{R H=0}^{100} I_{W s}(R H) \cdot n(R H) \cdot \Delta t
\end{aligned}
$$

ここで, $n(R H)$ は湿度が $R H$ となる累積回数である。 測定期間 $T$ 内で湿度が $R H$ になる確率密度関数を $\mathrm{f}(R H)$ とすれば, $n(R H) \cdot \Delta \mathrm{t}=T \cdot \mathrm{f}(R H)$ であるから

$$
Q_{T}=\sum_{R H=0}^{100} I_{W s}(R H) \cdot T \cdot \mathrm{f}(R H)
$$

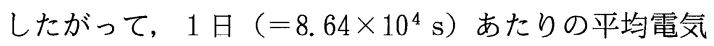
量（日平均電気量, $Q$ ) は

$$
\begin{aligned}
Q & =8.64 \times 10^{4} Q_{T} / T \\
& =8.64 \times 10^{4} \sum_{R H=0}^{100} I_{\mathrm{Ws}}(R H) \cdot \mathrm{f}(R H)
\end{aligned}
$$

として与えられる。このように, 腐食性の目安となる $Q$ は $W s$ と $R H$ の分布 $\mathrm{f}(R H)$ とによって決まる。

これを以下に図示してみる。まず, 湿度の確率密度関 数 $\mathrm{f}(R H)$ を Fig. 8 (a) に示す。湿度は $5 \%$ ごとに分

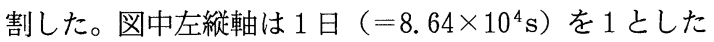
ときの累積時間 $8.64 \times 10^{4} \cdot \mathrm{f}(R H)[\mathrm{s}]$ である。この部

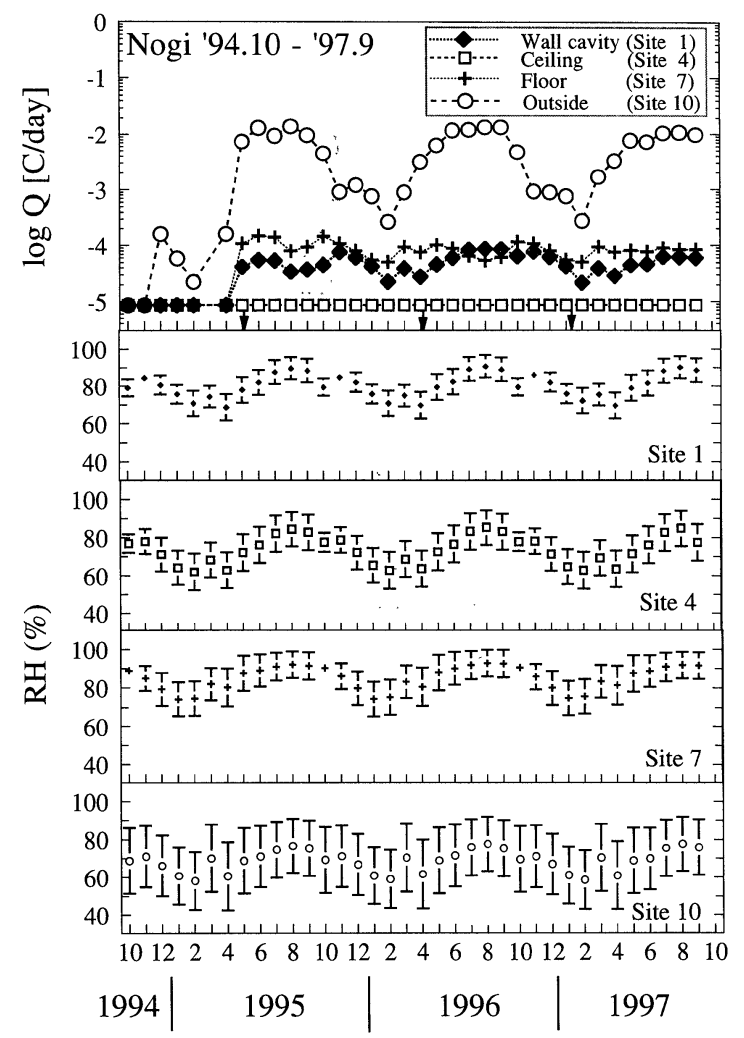

Fig.7 Monthly variation of daily average electricity, $Q$, and $R H$ at some sites in 3 year exposure ('94.10-'97.9).
位に,「海塩」を $W s=10^{-2} \mathrm{~g} / \mathrm{m}^{2}$ （屋外程度）付着させ たセンサを置いたときの, $I$ vs. $R H$ の関係は図（b）の ようになり, 各湿度での電気量 $(Q(R H))$ は図 $(\mathrm{a}),(\mathrm{b})$ の 縦軸の積 $\left(Q(R H)=8.64 \times 10^{4} I_{W s}(R H) \cdot \mathrm{f}(R H)\right)$ とし て図(c)のように与えられ,たとえば $R H=90 \%$ （87.5〜 $92.5 \%)$ の場合には図中の斜線部となる。このような計 算を 0 〜 $100 \%$ のすべての $R H$ について積算して日平均 電気量 $Q$ をえる。このようにして, 付着量の定常值之 $R H$ 条件とが与えられれば，その部位での $Q$ 算出でき ることになる。

\section{4 日平均電気量の「海塩」付着量および $R H$ 亡の 関係}

実際工業化住宅内において，直近の 1 年間（'96.10 ’ 97.9）における各暴露部位の日平均電気量 $(Q)$ 之海 塩相当付着量 $(W s)$ の実測値を Fig. 9 に示す。 $Q$ 之 $W s$ との関係におけるプロットは, Site 10 の屋外之 Site 1, 5, 7 と Site 4, 6 ( $Q$ は検出限界以下) の屋内之 に大きく分けられるが, 基本的には $W s$ に対応して $Q$

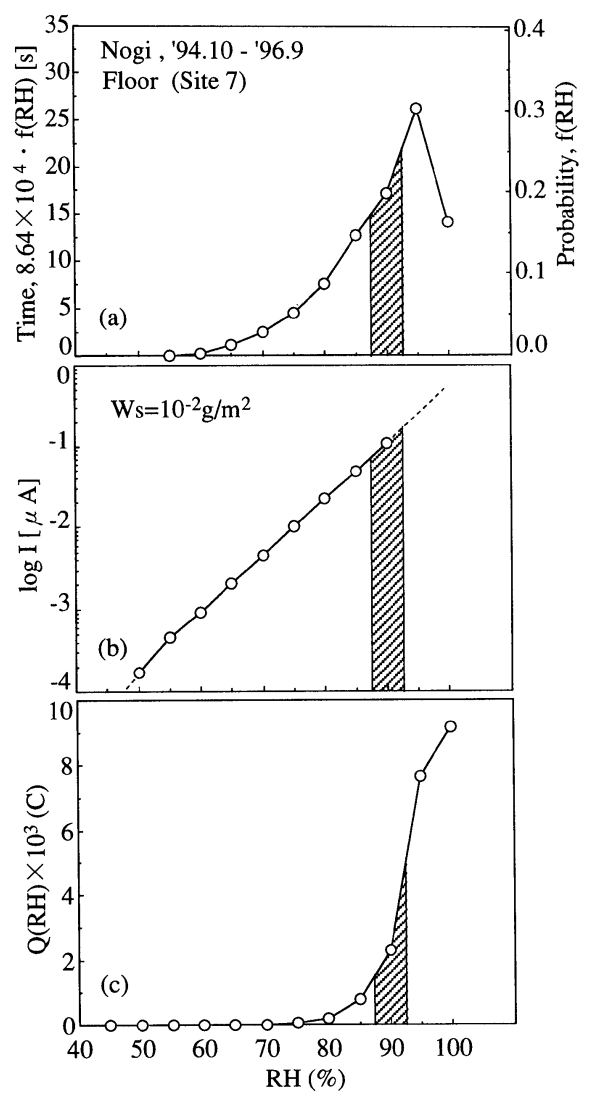

Fig.8 Accumulated time or probability of $R H$ at Site 7 (a), ACM sensor output, $I$, vs. $R H$ relationship with $W s=10^{-2} \mathrm{~g} / \mathrm{m}^{2}(\mathrm{~b})$, and calculated daily average electricity, $Q$ (c). 
が増加している。このことは, 日平均電気量に対応する であろう普通鋼（Fe とかく）の腐食速度が，まず海塩 相当付着量に依存することを示す。これを図中横軸方向 に示す「付着物からみた腐食性」とよぶ。センサ出力が 検出されない Site $4 \cdot 6$ における $Q$ は $8.64 \times 10^{-6} \mathrm{C} /$ day 未満であり，これに相当する付着量 (Ws) および普通 鋼の腐食速度 $C R(\mathrm{Fe})$ の検出限界は，それぞれ $W s=$ $10^{-4} \mathrm{~g} / \mathrm{m}^{2}$ および $C R(\mathrm{Fe})=2.25 \times 10^{-3} \mathrm{~mm} / \mathrm{y}$ である。

3.3で述べたように $Q$ は $R H$ にも依存する。そこで Fig. 3 で示した年間平均湿度が最も高い Site 7 (図中 $7 \mathrm{y}$ ）と最も低いSite 6 (同 $6 \mathrm{y}$ ), および月間平均湿度 が最も高い’97.8 の Site 7 (同 $7 \mathrm{~m}$ ) と最も低い’97.2 の Site 6 (同 $6 \mathrm{~m}$ ) における $R H$ の実測値に基づき種々 の「海塩」付着量における日平均電気量 $(Q)$ を算出し, 結果を Fig. 9 中に併せて示した。住宅内部位の $Q$ 值は, 月単位では $6 \mathrm{~m}$ と $7 \mathrm{~m}$, 年単位では $6 \mathrm{y}$ と $7 \mathrm{y}$ との間に あるであろう。同じ「海塩」付着量であっても，たとえ ば $W s=10^{-3} \sim 10^{-2} \mathrm{~g} / \mathrm{m}^{2}$ では $R H$ の月間での差が最も 大きい $6 \mathrm{~m}$ と $7 \mathrm{~m}$ とでは $Q$ 值に 100 倍弱の違いがあ

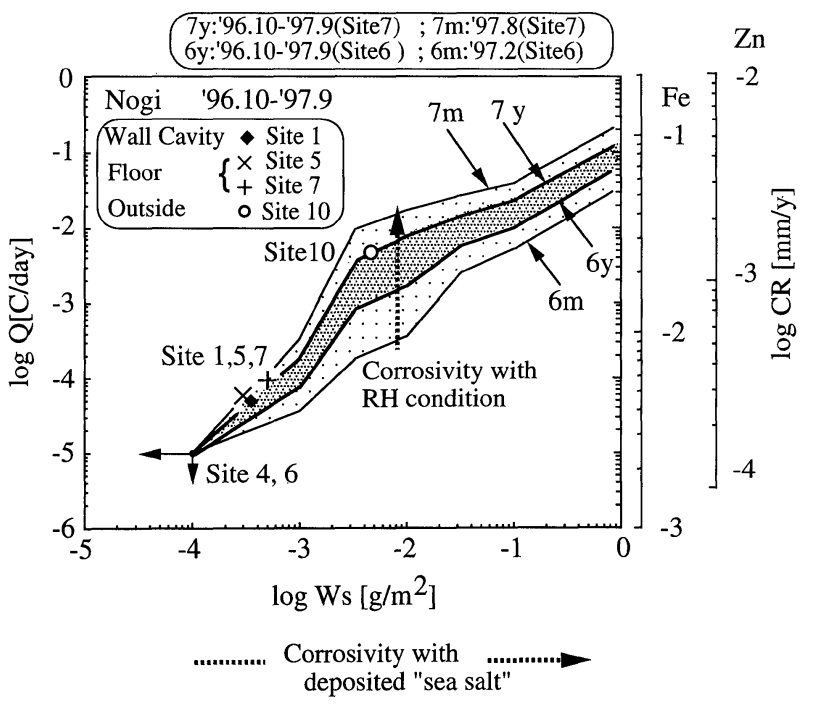

Fig.9 Corrosivity of indoor and outdoor sites for a residential house in terms of deposits (Ws) and humidity $(R H)$. Daily average electricity $(Q)$ on the left, obtained from ACM sensor, corresponds to corrosion rates of carbon steel $(\mathrm{Fe})$ and zinc $(\mathrm{Zn})$ on the right ordinates. The indoor sites with lower corrosivities ( $Q$ ) show lower $W s$ values, while the outdoor site 10 with the higher corrosivity $(Q)$ has higher $W s$ value. The $Q$ value depends also on $R H$. Under given values of $W s$ shown on the abscissa, $Q$ will vary in the ranges bound by the lines $7 \mathrm{~m}$ or $7 \mathrm{y}$, monthly or yearly highest humidity conditions observed at Site 7 , and the lines $6 \mathrm{~m}$ or $6 \mathrm{y}$, monthly or yearly lowest humidity conditions observed at Site 6 .

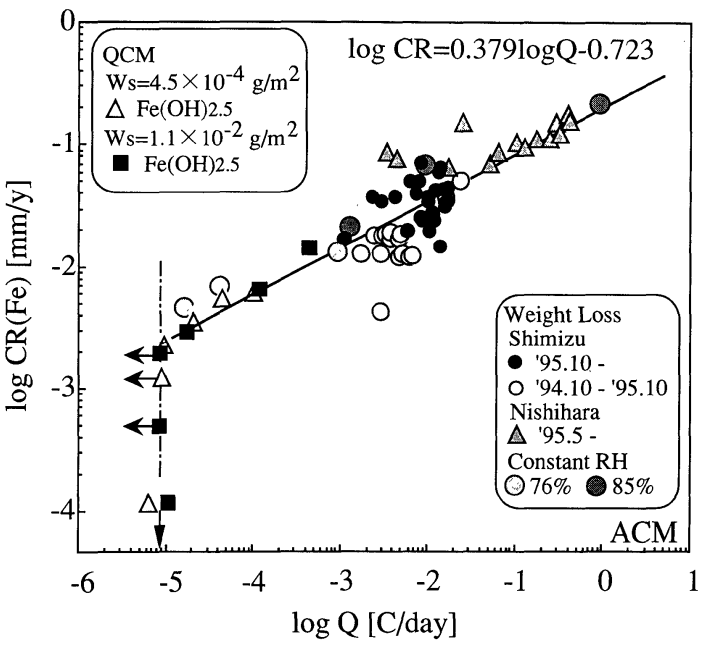

Fig.10 Relationship between corrosion rate of carbon steel, $C R(\mathrm{Fe})$, and daily average electricity, $Q$, obtained from ACM sensor.

る。この縦軸方向の変動は「RH 条件からみた 腐食性」を表すといえる。ただし，年間での変 動範囲（6 y と $7 \mathrm{y}$ の間）はより狭く, RH条 件が腐食性へ与える影響はより小さくなる。

\section{5 日平均電気量と普通鋼およびめっき亜 鉛の腐食速度との対応}

静岡県清水市および沖縄県西原町（琉球大 学) での雨の直接あたらないシェルター暴露試 験，または実験室での恒湿度試験における炭素 鋼板の重量減から求めた普通鋼 $(\mathrm{Fe})$ の腐食速 度 $C R(\mathrm{Fe})$ と, 同時に暴露した $\mathrm{ACM}$ センサ で測定した $Q$ との関係5),6)を Fig.10に示す。 図中の右上がりの直線は次式で表せる :

$\log C R(\mathrm{Fe})[\mathrm{mm} / \mathrm{y}]$

$$
=0.379 \log Q[\mathrm{C} / \text { day }]-0.723
$$

このような $Q$ と $C R(\mathrm{Fe})$ との関係を Fig. 9 お よび後述の Fig.13 の左右の縦軸に表示した。

次に, '94.10〜'97.9の 3 年間暴露しためっ き亜鉛の腐食速度を精密化学法によって湘定し た結果を Table 2 に示す。同表の $\max (3 \mathrm{y})$ は実測值中の最大值を $\mathrm{mm} / \mathrm{y}$ で表したもの で，腐食量を試料の暴露期間 $3 \mathrm{y}$ ではなく $W \mathrm{~s}$ が定常になった期間（'95.5〜'97.9:2.42 y） で除して求めた。これらの值は次節の耐用年数 の試算では $C R(\mathrm{Zn})-1$ とよぶ。なお, ' 94.10 〜'96.9の 2 年間暴露したものの同様の值, max (2y) も併せて示した。

こうして求めた $C R(\mathrm{Zn})$ を文献值と比較し てみる。まず, Fig. 11 は同一の屋外環境に同 
Table 2 Corrosion rate for zinc at each indoor site.

\begin{tabular}{|c|c|c|c|c|c|c|}
\hline \multirow[t]{2}{*}{ Site } & \multicolumn{4}{|c|}{ measured values for coupons } & $\max (3 y)$ & $\max (2 y)$ \\
\hline & \multicolumn{4}{|c|}{$\mathrm{g} / \mathrm{m}^{2} / 3 \mathrm{y}$} & $10^{-5} \mathrm{~mm} / \mathrm{y}$ & $10^{-5} \mathrm{~mm} / \mathrm{y}$ \\
\hline 1 & 0.274 & 0.328 & 0.353 & 0.694 & 4.02 & 4.45 \\
\hline 2 & 0.192 & 0.241 & 0.447 & - & 2.59 & - \\
\hline 3 & 0.172 & 0.258 & 0.279 & 0.372 & 2.16 & - \\
\hline 4 & 0.296 & 0.323 & 0.354 & 0.703 & 4.07 & 6.03 \\
\hline 5 & 0.509 & 0.775 & 1.212 & 1.344 & 7.79 & 7.81 \\
\hline 6 & 0.364 & 0.419 & 0.424 & 0.540 & 3.13 & - \\
\hline 7 & 0.878 & 1.150 & 2.194 & 2.275 & 13.2 & 14.0 \\
\hline 8 & 0.291 & 0.337 & 0.347 & 0.416 & 2.41 & 3.36 \\
\hline 9 & 0.258 & 0.280 & 0.295 & 0.518 & 3.00 & - \\
\hline
\end{tabular}

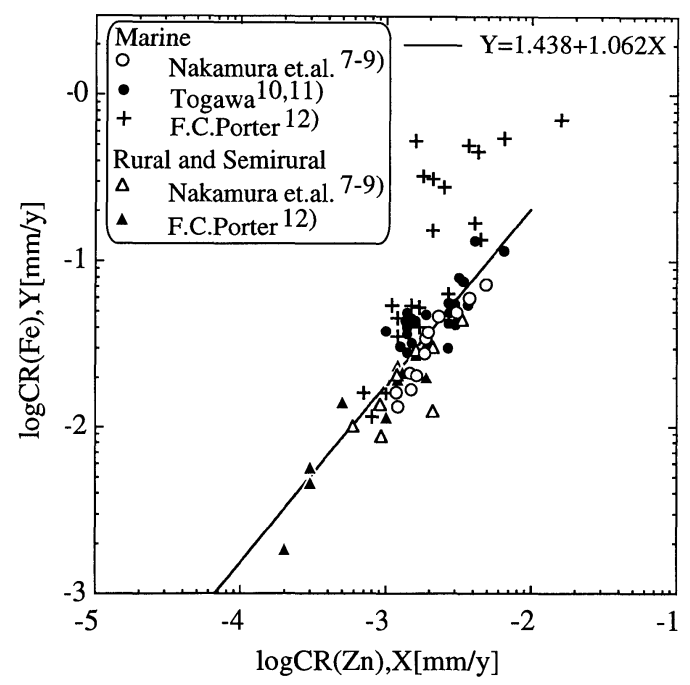

Fig.11 Reported corrosion rates of carbon steel and zinc exposed at outdoor sites.

時に暴露された $\mathrm{Fe}$ および $\mathrm{Zn}$ の腐食速度7) 12)で, Poter ${ }^{12)}$ らの海洋環境 (Marine, +印) での結果を除 けば，両腐食速度の関係は次式で表せる。

$\log C R(\mathrm{Fe})[\mathrm{mm} / \mathrm{y}]$

$$
=1.438+1.062 \log C R(\mathrm{Zn})[\mathrm{mm} / \mathrm{y}]
$$

また，(5)，(6)の両式より次式をえる :

$\log C R(\mathrm{Zn})[\mathrm{mm} / \mathrm{y}]$

$$
=0.357 \log Q[\mathrm{C} / \mathrm{day}]-2.035
$$

同様の両軸目盛りの Fig. 12 には,

(a) 野木の住宅内各部位における, ACM センサ出力 からうる $Q$ と(5)式の関係から求めた $C R(\mathrm{Fe})$ お よび Table 2 に示した $C R(\mathrm{Zn})$ の実测最大值, $\max (3 \mathrm{y})$,

および

（b）山陰地方の 6 戸の軽量鉄骨住宅内のそれぞれ 7 部 位および屋外 $(\oplus)$ に設置して 3 年経過した普通鋼 - 亜鉛めっき鋼板試片で求められた $C R(\mathrm{Fe}) \cdot C R$

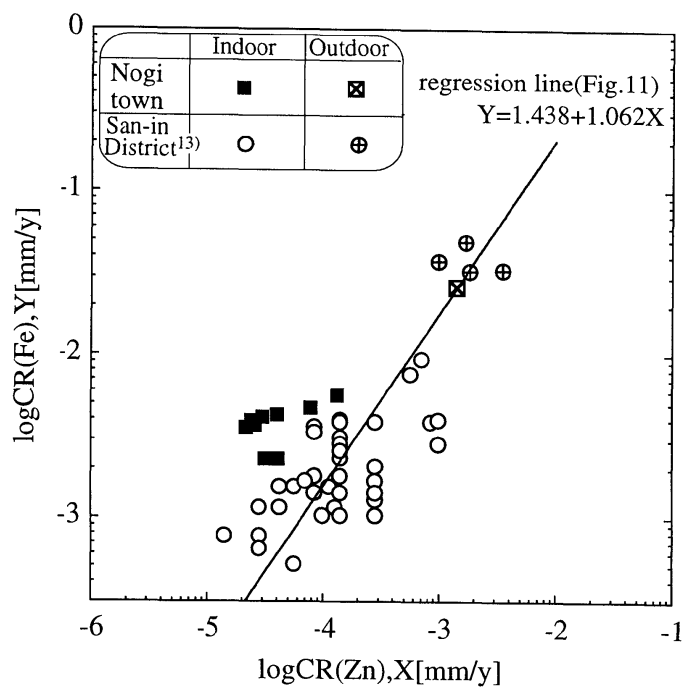

Fig.12 Corrosion rates of carbon steel ( $\mathrm{Fe}$ ) and zinc $(\mathrm{Zn})$ exposed for three years in prefabricated residential houses with respect to those exposured outdoor as shown in Fig. 11.

$(\mathrm{Zn})^{13)}$,

を記入した。また，右上がりの直線は Fig.11 中の回帰 線（(6)式）である。Fig.11中のデー夕はいずれも屋外 でのそれであるが, 值の小さいものほど暴露地の降雨量 が少なくなるなど屋内の条件に近づくのであろう。

Fig. 9 および後述の Fig.13 の右縦軸に目盛った $C R$ $(\mathrm{Zn})$ は, (7)式を用いて $Q$ から，あるいは(6)式を用い て $C R(\mathrm{Fe})$ から求めた後述の $C R(\mathrm{Zn})-2$ である。

\section{6 耐用年数の試算}

住宅内各部位ごとの亜鉛めっき鋼板の耐用年数を試算 した結果を Table 3 に示す。鋼材の許容腐食量は文献 14）に従い, 文献 15)：「低層建築物の構造耐力性能評価 に関する技術規定 (鉄鋼系)」に規定される值一構造耐 力上主要な部分に用いる鋼材の厚さ $2.3 \mathrm{~mm}$-の $10 \%$ を開断面における暴露面数 2 で除した値 $0.23 \mathrm{~mm} / 2$ と した。また，Znについては同じく文献 14)で「付着量 の90\%が腐食損失した時をもって耐用限界に達する」 と規定されることより, 所要めっき付着量の $90 \%$ を許 容腐食量とした。ここでの所要めっき付着量または厚さ は, 日本建築センターの評価 ${ }^{1)}$ に定める部位（d）ごと の值（e）を採った。同表において

a:Ws が定常になった’ 95.5〜'97.9 の ACM センサ

出力の日平均電気量 $Q$,

$\mathrm{b}: Q$ から(5)式を用いて求めた $C R(\mathrm{Fe})$

であり, 上述の腐食許容量 $0.23 \mathrm{~mm} / 2$ を $C R(\mathrm{Fe})$ で 除して鋼材による寿命期待值 $f$ をえる。また $C R(\mathrm{Zn})$ 
Table 3 Life expectancy estimated as corrosion allowance $-5 \%$ of minimum thickness $(2.3 \mathrm{~mm})$ required for steel member and $90 \%$ of specified coating thickness for zinc - divided by corrosion rate of carbon steel and zinc, respectively.

\begin{tabular}{|c|c|c|c|c|c|c|c|c|c|c|c|c|c|}
\hline & & $\mathrm{a}$ & $\mathrm{b}$ & $c$ & $\mathrm{c}^{\prime}$ & $\mathrm{d}$ & \multicolumn{2}{|c|}{ e } & $f$ & $\mathrm{~g}$ & $\mathrm{~g}^{\prime}$ & $h$ & $\mathrm{~h}^{\prime}$ \\
\hline & & $\begin{array}{l}\text { daily average } \\
\text { electricity, }\end{array}$ & $\mathrm{CR}(\mathrm{Fe})$ & \multicolumn{2}{|c|}{$\mathrm{CR}(\mathrm{Zn})^{*}$} & \multirow{2}{*}{\multicolumn{3}{|c|}{$\begin{array}{l}\text { site-class (d) and correspond- } \\
\text { ing minimum thickness (e) } \\
\text { of } \mathrm{Zn} \text { specified by } \mathrm{BCJ}^{1)}\end{array}$}} & life $(F e)$ & \multicolumn{2}{|c|}{$\operatorname{life}(\mathrm{Zn})$} & \multicolumn{2}{|c|}{ total life } \\
\hline & & Q & & -1 & -2 & & & & & -1 & -2 & -1 & -2 \\
\hline & & & & & & & & & $0.23 \mathrm{~mm} / 2 \mathrm{~b}$ & $0.9 \mathrm{e} / \mathrm{c}$ & $0.9 \mathrm{e} / \mathrm{c}^{\prime}$ & $f+g$ & $f+g^{\prime}$ \\
\hline & & C/day & $\mathrm{mm} / \mathrm{y}$ & \multicolumn{2}{|c|}{$\mathrm{mm} / \mathrm{y}$} & & $\mathrm{gm}^{-2}$ & $\mu \mathrm{m}$ & $\mathrm{y}$ & 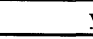 & $y$ & & \\
\hline Site & & & & & & & & & & & & & \\
\hline 1 & \multirow{5}{*}{ Wall cavity } & $4.5 \mathrm{E}-5$ & $4.3 \mathrm{E}-3$ & $4.02 \mathrm{E}-5$ & $2.6 \mathrm{E}-4$ & (3) & 75 & 10.5 & 27 & 235 & 36 & 262 & 63 \\
\hline 2 & & $3.0 \mathrm{E}-5$ & $3.7 \mathrm{E}-3$ & $2.59 \mathrm{E}-5$ & $2.3 \mathrm{E}-4$ & (3) & 75 & 10.5 & 31 & 365 & 42 & 396 & 73 \\
\hline 3 & & $2.8 \mathrm{E}-5$ & $3.6 \mathrm{E}-3$ & $2.16 \mathrm{E}-5$ & $2.2 \mathrm{E}-4$ & (3) & 75 & 10.5 & 32 & 438 & 43 & 470 & 75 \\
\hline 8 & & $3.6 \mathrm{E}-5$ & $3.9 \mathrm{E}-3$ & $2.41 \mathrm{E}-5$ & $2.4 \mathrm{E}-4$ & (3) & 75 & 10.5 & 29 & 392 & 40 & 421 & 69 \\
\hline 9 & & $4.1 \mathrm{E}-5$ & $4.1 \mathrm{E}-3$ & $3.00 \mathrm{E}-5$ & $2.5 \mathrm{E}-4$ & (3) & 75 & 10.5 & 28 & 315 & 38 & 343 & 66 \\
\hline 4 & \multirow{2}{*}{ Ceiling } & $<0.86 \mathrm{E}-5$ & $<2.3 \mathrm{E}-3$ & $4.07 \mathrm{E}-5$ & $<1.5 \mathrm{E}-4$ & (3) & 75 & 10.5 & $50<$ & 232 & $65<$ & $282<$ & $115<$ \\
\hline 6 & & $<0.86 \mathrm{E}-5$ & $<2.3 \mathrm{E}-3$ & $3.13 \mathrm{E}-5$ & $<1.5 \mathrm{E}-4$ & (3) & 75 & 10.5 & $50<$ & 302 & $65<$ & $352<$ & $115<$ \\
\hline 5 & \multirow{2}{*}{ Floor } & $5.8 \mathrm{E}-5$ & $4.7 \mathrm{E}-3$ & $7.79 \mathrm{E}-5$ & $2.8 \mathrm{E}-4$ & (1) & 110 & 15.4 & 24 & 178 & 49 & 202 & 73 \\
\hline 7 & & $9.3 \mathrm{E}-5$ & 5.6E-3 & $1.32 \mathrm{E}-4$ & $3.4 \mathrm{E}-4$ & (1) & 110 & 15.4 & 21 & 105 & 41 & 126 & 62 \\
\hline 10 & Outdoor & $5.4 \mathrm{E}-3$ & $2.6 \mathrm{E}-2$ & - & $1.4 \mathrm{E}-3$ & - & - & - & - & - & - & - & - \\
\hline
\end{tabular}

* $\mathrm{CR}(\mathrm{Zn})-1$ : maximum value measured for coupons (Table 2); $\mathrm{CR}(\mathrm{Zn})-2$ estimated value based on $\mathrm{Q}$ value(a) and the equation [7]

については,

c: Table 2 に示した実測の最大値, $C R(\mathrm{Zn})-1$

$\mathrm{c}^{\prime}$ : (6)式により（b) の $C R(\mathrm{Fe})$ から算出した推定 值, $C R(\mathrm{Zn})-2$

（以後， $C R(\mathrm{Zn})$ には実測值については“-1”を, 推定値については“-2”を付記する）

これらと上述の e の值とにより，めっき亜鉛による寿命 期待值 $g, g^{\prime}$ をえる。

なお, メンテナンス可能対象として建築センターの規 定がない屋外（Site 10）については，Qから(5)・(7)式 を用いて求めた $C R(\mathrm{Fe}) \cdot C R(\mathrm{Zn})-2$ の值のみを Table 3 に記載するにとどめた。

$\mathrm{Zn}$ の腐食速度として, 実測最大值 $C R(\mathrm{Zn})-1$ (c) を採った場合の寿命（g）は，いずれの部位においても より大きな值になる。より小さい值を与える $C R(\mathrm{Zn})-2$ （ $c^{\prime} ）$ を用いた場合の寿命 $\left(\mathrm{g}^{\prime}\right)$ は, 天井・小屋裏(Site $4,6)$ で 65 年超と比較的大きいほかは, 壁内の 5 か所 の部位で 36〜 43 年, である。以上の部位は建築セン ターの区分で (3) に当たる。これらより腐食性が㛜しい とされる床下（Site 5, 7 ) 一同上の部位区分 (1)一におい ても所要めっき厚を増すことにより $49 \cdot 41$ 年と, 同レ ベルの寿命が確保されていることがわかる。結局, めっ き亜鉛と下地鋼材とからなる亜鉛めっき鋼材としての寿 命期待値は, $C R(\mathrm{Zn})-2\left(\mathrm{c}^{\prime}\right)$ による評価 $\left(\mathrm{h}^{\prime}\right)$ で 60 年以上, $C R(\mathrm{Zn})-1$ (c) による評価で 120 年以上（h） となっている。
以上の試算は，同センターの規定する必要限のめっき 仕様を仮定した場合の值であって, 実際に本報で調査し た野木の工業化住宅のようにこれより上位の仕様が採用 されていれば，寿命期待值はさらに大きくなることはい うまでもない。

\section{7 住宅内環境の腐食性}

Table 3 のように得られた腐食速度を文献 14)の值と 比較し, 結果を Table 4-1に示す。まず, 屋外（Site 10） における腐食速度は, Fe および $\mathrm{Zn}$ についてそれぞれ $2.6 \times 10^{-2}$ および $1.4 \times 10^{-3} \mathrm{~mm} / \mathrm{y}$ である。これらを Table 4-1 中 (2) に示した。文献 14)による対応する值 は, Table 4-1 中 (2) に示す表面無処理鋼材の年間腐食 量 $\alpha_{\mathrm{s}}=5 \times 10^{-2}$ ，および標準地域における亜鉛めっきの 年間腐食量 $\alpha_{\mathrm{Zn}}=11 \mathrm{~g} /\left(\mathrm{m}^{2} \cdot \mathrm{y}\right)=1.5 \times 10^{-3} \mathrm{~mm} / \mathrm{y}$ であ る。これらと比較して Site 10 の $C R(\mathrm{Fe})$ は約 $1 / 2$ と小 さく, $C R(\mathrm{Zn})-2$ はほぼ同じである。

次に, 屋内における最も高い腐食速度は Site 7 でえ られ, Table 4-1 中 (1) に示すように, Fe については 5.6 $\times 10^{-3} \mathrm{~mm} / \mathrm{y}, \mathrm{Zn}$ については $1.3 \times 10^{-4}(-1)$ または $3.4 \times 10^{-4}(-2) \mathrm{mm} / \mathrm{y}$ である。先に述べたように, 屋 外 (Site 10) (2) においては実測值 (-1) がえられてい ないため(6)式から推定した值（-2）を用いた。これら の屋内/屋外の比 (同 (1)/(2) ) は $\mathrm{Fe}$ で約 0.22 および $\mathrm{Zn}$ で 0.093 または 0.24 で, 文献 14）での対応する比, 露 出度係数 BX 3 (非露出/常時乾燥) / BX 4 (半露出/湿潤 ・乾燥の繰り返し $)=1 / 6 \fallingdotseq 0.17(\mathrm{Fe})$ および $1 / 8 \fallingdotseq 0.13$ 
Table 4-1 Comparison of corrosion rate between outdoor and indoor sites for carbon steel ( $\mathrm{Fe})$ and zinc $(\mathrm{Zn})$.

\begin{tabular}{lllll|l|l}
\hline \multicolumn{4}{c|}{ Corrosion rate (mm/y) } & \multicolumn{2}{c}{ ratio } \\
\multicolumn{2}{c|}{ 1)indoor (Site 7) } & (2)outdoor(Site 10) & (2) & $14)$ & (1) $/$ (2) & $\left.\mathrm{BX} 3 / \mathrm{BX} 41^{4}\right)$ \\
\hline $\mathrm{Fe}$ & $5.6 \times 10^{-3}$ & $2.6 \times 10^{-2}$ & $5 \times 10^{-2}$ & $\left(\alpha_{\mathrm{S}}\right)$ & 0.22 & $1 / 6=0.17$ \\
\hline $\mathrm{Zn}$ & $\begin{array}{l}1.3 \times 10^{-4}(-1) \\
3.4 \times 10^{-4}(-2)\end{array}$ & $1.4 \times 10^{-3}(-2)$ & $1.5 \times 10^{-3}$ & $\left(\alpha_{\mathrm{Zn}}\right)$ & $\begin{array}{l}0.093 \\
0.24\end{array}$ & $1 / 8=0.13$ \\
\hline
\end{tabular}

Table 4-2 Comparison of $\mathrm{SO}_{3}$ absorbed in $\mathrm{PbO}_{2}$ between outdoor and indoor sites.

\begin{tabular}{cc|cc}
\hline \multicolumn{2}{c|}{$\mathrm{mgSO}_{2} / 100 \mathrm{~cm}^{2} /$ day } & \multicolumn{2}{c}{ ratio } \\
(1)indoor (Site 1) & (2)outdoor(Site 10) & (1) $/$ (2) & Fukuda et.al. F) $^{2}$ \\
\hline 0.001 & 0.026 & $1 / 26$ & $1 / 20$ \\
\hline
\end{tabular}

(Zn) にそれぞれおおよそ等しい。

長沼ら ${ }^{16)}$ は, $\mathrm{Fe} \cdot \mathrm{Zn}$ など各種金属の腐食速度と海塩 粒子飛来量との倉庫屋内/屋外の比が，いずれも約 $1 / 10$ であることを報告している。Fig.6（3.2）に示した屋 内/屋外の比, $1 / 10$, はこれにほぼ等しく, 污染物質の 堆積速度を調べた福田ら ${ }^{17)}$ による固体化合物中 $\mathrm{Cl}^{-}$の 屋内/屋外比, 約 $1 / 20$, よりやや大きい。なお, 同じ報 告17)において $\mathrm{PbO}_{2}$ で捕集される $\mathrm{SO}_{3}$ の堆積速度の屋 内/屋外比, 約 1/20, については, Table 4-2 に示す実 測值, 約 $1 / 26$, と近い值となっている。Zn の腐食を最 も促進する亜硫酸ガス濃度は, $\mathrm{mgSO}_{3} / 100 \mathrm{~cm}^{2} /$ day で 表して工業地帯・都市部で $0.10 \sim 0.30$, 山間部の最も 低い箇所で 0.000 0. 001 と報告 ${ }^{18)}$ されている。Table 4-2 によれば, 屋外の Site 10 での同濃度 0.026 は, 同 上の報告による筑波田園部（0.023） と琵琶湖近くの山 間部（0.027）との中間に位する。これに対し屋内の Site 1 では 0.001 で, 上述の山間部など最も低い箇所と 同程度の低い值を示している。

以上のように, 住宅内環境は付着物量が少ないことに 対応して腐食速度が低く, 現段階でもかなり穏和な環境 にあることがわかる。しかし，Fig. 3でみたように床 下や壁内部の湿度は屋外より高い。もし，床下・壁内な ごの構造駆体内部を付着物をもちこむことなくより低い 湿度に制御できれば，低湿度と極低付着物量との相乗効 果によるさらなる長期健全性を達成できよう。

3. 3 の手法により, 相対湿度 $R H$ が一定值に保たれる と仮定して計算した日平均電気量 $Q$ と海塩相当付着量 $W s$ との関係を Fig. 13 に示す。先に Fig. 9 に示した Site 10 の $(Q, W s)$ 值のプロットが Fig. 13 中で占め る位置から判断すると, 同 Site の湿度条件が対応する 一定湿度（相当定湿度）はおよそ $R H=90 \%$ ありり，
同様に屋内部位（Site 1，5，7）のそれも $R H=80 \sim 90 \%$ に対応する。

Fig.13 によると, 屋内の $W s$ 值をやや高めの $10^{-3}$ $\mathrm{g} / \mathrm{m}^{2}$ と仮定する場合でも， $R H$ を 50 \%以下に制御す ることにより $\mathrm{ACM}$ センサの出力は検出限界以下にす ることができる。すなわち Table 3 でみて Site 4, 6 (天 井裏, 小屋裏）に相当する秪和な環境腐食性一同表でみ て 65 年を超え $\left(\mathrm{g}^{\prime}\right)$ ・約 200 年 $(\mathrm{g})$ というめっき亜鉛 の寿命一が期待できる。

\section{4. まとめ}

$\mathrm{ACM}$ 型腐食センサを実際工業化住宅内各部位に暴露 し， 3 年間経過時点で腐食性評価をまとめた。

1）住宅内部位ごとの腐食性の尺度としての ACMセ ンサ出力の日平均電気量 $Q$ は, 相対湿度 $R H$ 之海 塩相当付着量 $W s-\mathrm{ACM}$ センサ出力の対 $R H$ 特性

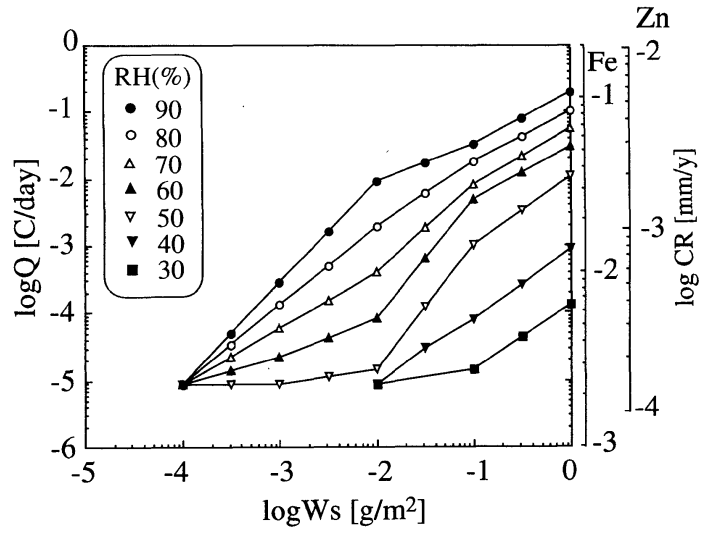

Fig.13 Relationship between daily average electricity, $Q$, and deposited sea salt, $W s$, calculated under constant $R H$ condition. 
から決定できる一とに依存する。

2） $Q$ 之炭素鋼の腐食速度 $C R(\mathrm{Fe})$ との間にはよい 対応関係があり，Qから $C R(\mathrm{Fe})$ を推定できる。 このことは，精度はやや劣るがめっき亜鉛の腐食速 度 $C R(\mathrm{Zn})$ についてもあてはまる。

3）屋内での腐食速度は，鋼材・めっき亜鉛とも屋外 の $1 / 5$ と低く，これは付着物量 $W s$ が屋内で少ない ことと対応している。亜鉛の腐食速度を大きく促進 する硫黄酸化物量も屋内では $0.001 \mathrm{mg} / 100 \mathrm{~cm}^{2}$ / day と非常に少なく，屋外の $1 / 26$ であった。

4）普通鋼 ・ っっき亜鉛の腐食速度と日本建築セン ターが規定するめっき厚さなどに基づいて，鋼材と めっき亜鉛とによる腐食寿命期待值を部位ごとに試 算した。

5）屋内各部位において，付着物量と湿度とをさらに 低減することにより，より長い寿命が期待できる。 例えば，海塩相当付着量 $W s$ が $10^{-3} \mathrm{~g} / \mathrm{m}^{2}$ のとき, 相対湿度 $R H$ を 50 \%以下に保てば，ACM センサ の検出限界以下の穞和な環境腐食性が達成できる。

\section{謝辞}

本研究は, (財) 日本建築センターの平成 6 年度研究 助成に基づき実施した。実地測定において同センター評 定部住宅課長金岡宏幸氏，(社)プレハブ建築協会幹事 社（当時）の積水ハウス株式会社阿蘇太美夫氏・住田安 司氏のご尽力を賜わった。記して樑謝する。

(Manuscript received April 22, 1998; in final form July 31,1998 )

\section{文献}

1) 日本建築センター: ビルディングレター '96. 3, 37 (1996).
2 ）元田慎一，鈴木揚之助，篠原 正，兒島洋一，辻 川茂男, 押川 渡, 系村昌祐, 福島敏郎, 出雲茂 人: 材料と環境，43，550（1994）。

3 ）元田慎一, 鈴木揚之助, 篠原 正, 辻川茂男, 押 川 渡, 系村昌祐, 福島敏郎, 出雲茂人: 材料之 環境, 44, 218 (1995).

4）松本雅充 : 第 111 回腐食防食シンポジウム資料, 腐食防食協会, p.26（1996）。

5 ）元田慎一, 鈴木揚之助, 篠原 正, 辻川茂男 : 第 111 回腐食防食シンポジウム資料, 腐食防食協 会, p. 1 (1996).

6 ）押川 渡, 系村昌祐, 篠原 正, 辻川茂男 : 第 111 回腐食防食シンポジウム資料, 腐食防食協 会, p. 7 (1996).

7 ）中村 素：防蝕技術，12，55（1963）。

8 ）堀川一男, 瀧口周一郎, 石津善雄, 金指元計：防 蝕技術，16，153（1967）.

9 ）中村 素, 尾間一彦, 菅野照造，平井陽一: 防蝕 技術, 16，467（1967）。

10） ISO/TC156/JWG 4, 外川靖人：第 36 回腐食防 食討論会講演集, p.217 (1989).

11） ISO/TC156/JWG 4, 外川靖人, 伊藤哲司 : 第 38 回腐食防食討論会講演集, p.157 (1991).

12) F. C. Porter: "Corrosion Resistance of Zinc and Zinc Alloys", Marcel Decker Inc., New York, p.101 (1994).

13）石本徳三郎, 宮下 優 : 日本建築学会大会学術講 演梗概集，p.1183（1987）.

14）建設大臣官房技術調查室監修，(財)国土開発技 術研究センター建築物耐久性向上技術普及委員会 編:「鉄骨造構造物の耐久性向上技術」, 技報堂出 版 (1986).

15）日本建築センター：ビルディングレター '97. 9, 220 (1997).

16）長沼 仁，大黒 紘 : 第 6 回防錆技術発表大会講 演予稿集, p.104 (1986).

17）福田芳雄, 福島敏郎, タン・チェン・ミン, 吉原 一紘, 藤原 純: 表面技術, 41，1059 (1990).

18）建設省土木研究所，（社)鋼材俱楽部，（社）日本 橋梁建設協会 : 耐候性鋼材の橋梁への適用に関す る共同研究報告書 (IX), p. 5 （1989）. 